\title{
Geokongres ved Oslo - geologisk olympiade i Norge
}

\section{Af Ulla V. Hjuler, GeologiskNyt}

Fra den 6. til den 14. august bliver Oslo og Lillestrøm invaderet af geologer. 6.000 videnskabsmænd fra 120 lande vil i de 9 dage, som verdenskongressen varer, mødes til foredrag, paneldiskussioner, ekskursioner og "poster sessions". Desuden vil der være forskellige udstillinger. På selve åbningsdagen vil Norges Kong Harald være til stede - han er nemlig protektor for kongressen.

Forskningskonferencen er den største nogensinde i Norge. Den geologiske verdenskongres IGC (International Geolocigal Congress) er siden 1878 i Paris arrangeret med 4 års mellemrum. Årets kongres er den 33 i rækken.

\subsection{0 bidrag}

Pr. 1. maj er der indsendt ca. 6.500 bidrag til foredragsprogrammet, der strækker sig over alle 9 dage. Formentlig vil kongressen også tiltrække mange af udstillerne samt leverandører.

Verdenskongressens generalsekretær Anders Solheim fra NGI (Norges Geotekniske Institut i Oslo) anslår, at der kommer 6.0007.000 deltagere fra hele Verden. På grund af arrangementets størrelse er det derfor ved at være for sent at bestille værelser på de fleste hoteller i Oslo, Lillestrøm og Gardermoen.

Der vil være aktiviteter for Oslos befolkning og besøgende på Universitetspladsen $\mathrm{i}$ centrum hver dag. Botanisk Have på Tøyen og det nyopførte operahus i Bjørvika vil komme til at huse sociale, kulturelle og faglige aktiviteter.

\section{Dagens tema}

Hver dag vil relevante foredrag omhandle følgende temaer:

\section{Biodiversitet og udvikling}

Klima

"Geohazards"

Vand og helbred

Mineralressourcer

Energi

Jorden og "det derude"
Mere end 80 internationalt anerkendte eksperter vil bidrage til "Dagens tema". Hver dag afholdes der et nøgleforedrag med en til lejligheden specielt inviteret ekspert, som vil diskutere dagens tema.

Det er i øvrigt meningen, at der skal køre 30 parallelle sessioner samtidig hver dag. Grundet det høje deltagerantal har man således været nødt til "bygge" ekstra auditorier inde i de store udstillingshaller. Desuden arrangeres der 35 ekskursioner før, under og efter kongressen. Turene går til Grønland, Svalbard og Ukraine samt ikke mindst i nærområderne, hvor Oslo-feltet, som strækker sig fra Langesund i syd til Brumunddal i nord, er en unik geologisk lokalitet i verdenssammenhæng.

\section{Dansk deltagelse}

Også Danmark er repræsenteret og foreløbig er der over 60 deltagere fra Danmark. Bl.a. skal Minik Rosing fra Geologisk Museum i København holde foredrag på kongressens første temadag (Biodiversitet og udvikling) med titlen: "The impact of Life on the young Earth", og Henrik Svensmark fra DTU Space holder et foredrag på anden temadag (Klima) med titlen:"Cosmoclimat ology: the influence of Cosmic rays on Climate". Samme dag slutter vores klima- og energiminister Connie Hedegaard dagen af med foredraget: "Climate Science and the need for action".

Ud over nordmændene, der naturligvis selv stiller med det største antal, kommer der mange deltagere fra USA, Rusland, England, Italien, Kina, Tyskland, Italien, Japan, Sverige og Østrig.

\section{Rovøgle bliver stor attraktion}

Sidste år fandt den norske palæontolog Jørn Hurum 40 fossile havdyr på Svalbard. Det største af dem er nu samlet - "Monstret" kalder nordmændene det. Det er $15 \mathrm{~m}$ langt og det største havfossil, man har fundet. Den tilhører ordenen Plesiosaurus - populært kaldet "svaneøgle", men er dog mere korthalset end sin fætter.

Den fossile rovøgle er nu ikke i sin helhed med ved kongressen. Man vil kunne se dele af skelettet udstillet i Lillestrøm. Men til gengæld er der indkøbt et "svævende" monster i samme størrelse - $15 \mathrm{~m}$ langt, $4 \mathrm{~m}$ bredt og $8 \mathrm{~m}$ højt - til den beskedne sum af 150.000 Nkr. Det er en specialsyet kopi, der er fremstillet i Californien, USA. Det gi-

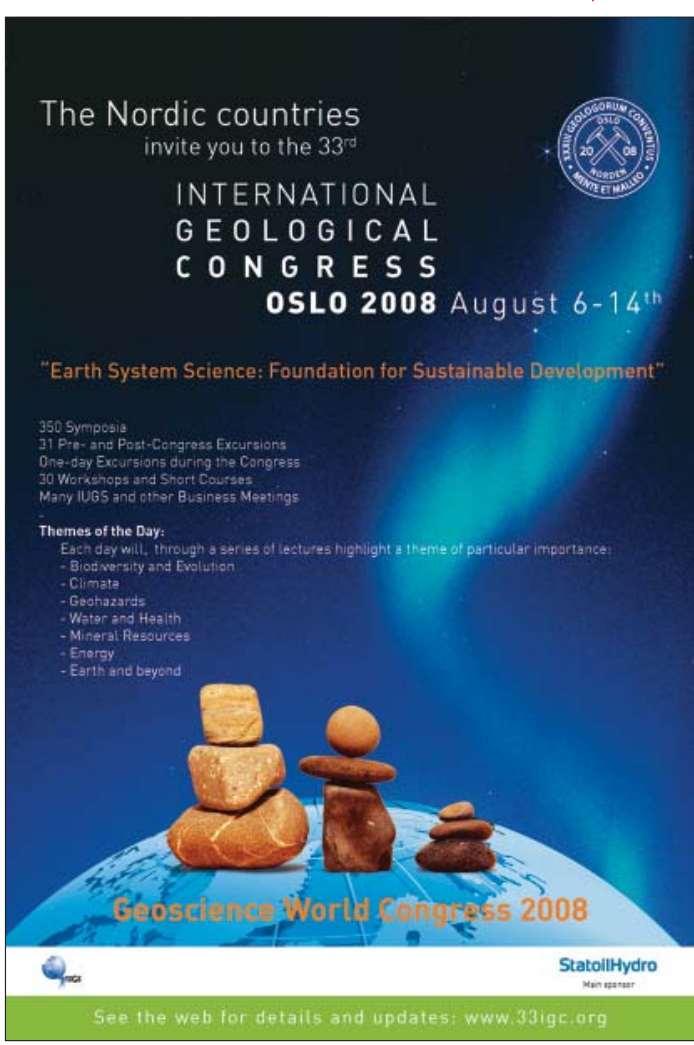

Den officielle plakat, der fremstillet til kongressen.

gantiske badedyr bliver pustet op lige inden kongressens begyndelse og kommer til at svæve over byen i en uge.

Jørn Hurum holder foredrag om den fossile rovøgle på temadagen om biodiversitet og udvikling.

\section{Info}

På hjemmesiden kan man registrere sig, finde oplysninger om foredrag (samt læse abstracts), ekskursioner, work shops og få generel information om Oslo, transportmuligheder, hotelbestilling osv. Desuden kan man se, hvilke udstillere der kommer samt en plan over kongrescentrets udstillingsområde.

Se mange flere oplysninger på: http://www.33igc.org 